\title{
Origin of Subsequent Malignant Neoplasms in Patients with History of Testicular Germ Cell Tumor
}

\author{
Eric C. Umbreit ${ }^{1,+}{ }^{,}$Bilal A. Siddiqui ${ }^{2,+}{ }^{(\mathbb{D}}$, Michael J. Hwang ${ }^{3}$, Aron Y. Joon ${ }^{4}$, Tapati Maity ${ }^{1}$, \\ Mary E. Westerman ${ }^{1}$, Kelly W. Merriman ${ }^{5}$, Hussam Alhasson ${ }^{2}$, Joma Uthup ${ }^{2}$, Tao Guo ${ }^{3}$, \\ Joseph A. Moore ${ }^{2}$, John F. Ward ${ }^{1}$, Jose A. Karam ${ }^{1}$, Christopher G. Wood ${ }^{1}$, Louis L. Pisters ${ }^{1}$, \\ Miao Zhang ${ }^{3}$ and Shi-Ming Tu ${ }^{1, *}$ \\ 1 Department of Urology, University of Texas MD Anderson Cancer Center, Houston, TX 77030, USA; \\ umbreite@gmail.com (E.C.U.); TMaity@mdanderson.org (T.M.); MEWesterman@mdanderson.org (M.E.W.); \\ JFWard@mdanderson.org (J.F.W.); JAKaram@mdanderson.org (J.A.K.); CGWood@mdanderson.org (C.G.W.); \\ lpisters@mdanderson.org (L.L.P.) \\ 2 Department of Genitourinary Medical Oncology, University of Texas MD Anderson Cancer Center, \\ Houston, TX 77030, USA; basiddiqui@mdanderson.org (B.A.S.); hussam.alhasson@gmail.com (H.A.); \\ JUthup1@mdanderson.org (J.U.); JAMoore6@mdanderson.org (J.A.M.) \\ 3 Department of Pathology, University of Texas MD Anderson Cancer Center, Houston, TX 77030, USA; \\ MJHwang@mdanderson.org (M.J.H.); TGuo@mdanderson.org (T.G.); MZhang8@mdanderson.org (M.Z.) \\ 4 Department of Biostatistics, University of Texas MD Anderson Cancer Center, Houston, TX 77030, USA; \\ AYJoon@mdanderson.org \\ 5 Department of Tumor Registry, University of Texas MD Anderson Cancer Center, Houston, TX 77030, USA; \\ kmerriman@mdanderson.org \\ * Correspondence: STu@mdanderson.org; Tel.: +1-713-563-7268 \\ + These authors contributed equally to this manuscript.
}

Received: 6 October 2020; Accepted: 10 December 2020; Published: 14 December 2020

Simple Summary: Although testicular germ cell tumor (TGCT) carries a high cure rate, some patients still die from it. We investigated the genetic landscape and cellular origins of cancers that develop later in life after treatment for TGCT and found evidence that a common progenitor cell might be responsible for both. This study shows the possible importance of stem-like cells in the development of cancer.

\begin{abstract}
Although genetic changes may be pivotal in the origin of cancer, cellular context is paramount. This is particularly relevant in a progenitor germ cell tumor and its differentiated mature teratoma counterpart when it concerns tumor heterogeneity and cancer dormancy in subsequent second malignancies (subsequent malignant neoplasms (SMNs)). From our tumor registry database, we identified 655 testicular germ cell tumor (TGCT) patients who developed SMNs between January 1990 and September 2018. Of the 113 solid organ SMNs, 42 had sufficient tumor tissue available for fluorescence in situ hybridization (FISH) analysis of isochromosome 12p [i(12p)]. We identified seven additional patients for targeted DNA and RNA sequencing of teratomas and adjacent somatic transformation. Finally, we established cell lines from freshly resected post-chemotherapy teratomas and evaluated the cells for stemness expression by flow cytometry and by the formation of teratomas in a xenograft model. In our cohort, SMNs comprising non-germ cell tumors occurred about 18 years after a diagnosis of TGCT. Of the 42 SMNs examined, 5 (12\%) contained i(12p) and $16(38 \%)$ had $12 \mathrm{p}$ gain. When comparing a teratoma and adjacent somatic transformation, targeted DNA and RNA sequencing demonstrated high concordance. Studies of post-chemotherapy teratoma-derived cell lines revealed cancer-initiating cells expressing multipotency as well as early differentiation markers. For the first time, we demonstrated the prevalence of i(12p) in SMNs and the presence of progenitor cells embedded within mature teratomas after chemotherapy. Our findings suggest a
\end{abstract}


progenitor stem-like cell of origin in SMN and TGCT and highlight the importance of cellular context in this disease.

Keywords: testicular cancer; second malignancy; somatic transformation; isochromosome 12p; teratoma; cancer stem cell

\section{Introduction}

Although testicular germ cell tumor (TGCT) carries a high cure rate (exceeding 90\%), a subset of patients still succumb to it [1-3]. Identification of patients at risk for a lethal TGCT remains a key unmet need. Mortality from TGCTs can occur in part due to the somatic transformation of teratomas into non-TGCT subtypes (e.g., sarcoma, primitive neuroectodermal tumor, or adenocarcinoma) or the development of subsequent malignant neoplasms (SMNs). Somatic transformation occurs in $2.4 \%$ of primary nonseminomatous germ cell tumors (NSGCTs) and 3.4\% of residual metastatic NSGCTs after chemotherapy [3]. Mortality from somatic transformation appears to be driven by transformation in metastatic lesions (with a mortality rate of $68 \%$ ), rather than transformation of the primary testicular tumor [3].

Groot et al. reported that the cumulative incidence of SMNs is about $10 \%$ over the 25 -year period following treatment of TGCT [4]. They attributed SMNs to the accumulation of deleterious mutations related to DNA damage from prior chemotherapy and/or radiotherapy, as well as to the process of somatic transformation [4]. Both somatically transformed tumors and TGCTs contain the isochromosome 12p [i(12p)] [5], but it is unclear whether SMNs also harbor i(12p). Additionally, a pure seminoma (which does not classically undergo somatic transformation) may also evolve into an i(12p)-containing SMN without prior exposure to chemotherapy or radiotherapy, highlighting the role of lineage plasticity and cellular context in the development of SMNs [6-10].

We sought to use $\mathrm{i}(12 \mathrm{p})$ as a genetic marker to determine if an SMN represents a new primary malignancy or is related to a prior primary TGCT. Approximately $80 \%$ of TGCTs harbor i(12p); the remaining $20 \%$ carry other chromosomal changes involving chromosome $12 p$, including increases in copy number, tandem duplication, or transposition [11-14]. The consistent involvement of 12p may implicate common gene elements located on that chromosome, including C13-16CND2, SOX5, JAW1, KRAS, NANOG, and GDF3, in the pathogenesis of TGCT [14-16]. Importantly, i(12p) is almost never associated with other malignancies without previous or concurrent TGCT [17]. However, 12p by itself is insufficient for the development of TGCT-in Pallister-Killian mosaic syndrome [18], patients with $\mathrm{i}(12 \mathrm{p})$ or tetrasomy $12 p$ do not develop TGCT. Therefore, while i(12p) does not necessarily produce TGCT, its high prevalence in TGCT makes it a useful genetic marker to establish potential links between TGCT and SMN.

In this study, we investigated the cellular origin of SMN, somatically transformed teratoma, and surgically excised post-chemotherapy teratoma. We evaluated the prevalence of $i(12 p)$ (and gain of $12 p$ ) by fluorescence in situ hybridization (FISH) on various SMNs in patients with a history of TGCT. In addition, we performed targeted DNA (T200) and RNA sequencing (RNAseq) of matched metastatic teratomas and somatically transformed tumors from seven patients. Finally, we established cell lines from post-chemotherapy residual teratomas of two patients and identified progenitor cell populations by flow cytometry and the formation of teratomas in xenograft. Our findings suggest that an early progenitor cell in TGCT drives lethal phenotypes, including SMN and somatic transformation, highlighting the importance of cellular context in our understanding of this disease. 


\section{Results}

\subsection{Detection of $i(12 p)$ and Gain of $12 p$ in SMNs}

The study cohort comprised 43 SMNs from 42 patients (Table 1). Two separate patients with SMNs positive for $\mathrm{i}(12 \mathrm{p})$ underwent testing of normal adjacent tissue without cancer as a negative control. We did not detect $\mathrm{i}(12 \mathrm{p})$ or $12 \mathrm{p}$ gain in the normal tissues. The median age at the time of diagnosis of primary TGCT was 41 years (range: 20-68). The median age at the time of diagnosis of SMN was 59 years (range: 34-86). The median time to diagnosis of SMN from diagnosis of primary TGCT was 18 years (range: $0-57)$. From the 42 cases of SMNs, 21 (50\%) were found to carry either $\mathrm{i}(12 \mathrm{p})(n=5,12 \%)$ or additional copies of chromosome 12 without apparent gain of $12 \mathrm{p}(n=16$, $38 \%$ ). The clinicopathologic characteristics and FISH results of these SMNs are listed in Table 2. Representative images demonstrating detection of $\mathrm{i}(12 \mathrm{p})$ or additional copies of chromosome 12 without $\mathrm{i}(12 \mathrm{p})$ are shown in Figure 1 Aand $1 \mathrm{~B}$ respectively. The negative control is depicted in Figure 1C. FISH data by tumor site are provided in Figure S1a.

Table 1. Distribution of subsequent malignant neoplasms (SMNs) in testicular germ cell tumor (TGCT) cohort.

\begin{tabular}{|c|c|}
\hline Second Malignancy & Number of Cases \\
\hline Total & 43 \\
\hline Gastrointestinal & 9 \\
\hline Colorectal & 6 \\
\hline Pancreas & 2 \\
\hline Adenocarcinoma & 1 \\
\hline Neuroendocrine & 1 \\
\hline Esophageal & 1 \\
\hline Lung & 7 \\
\hline Squamous & 3 \\
\hline Adenocarcinoma & 3 \\
\hline Neuroendocrine & 1 \\
\hline Genitourinary & 15 \\
\hline Renal cell & 8 \\
\hline Clear cell & 7 \\
\hline Papillary & 1 \\
\hline Urothelial & 5 \\
\hline Bladder & 4 \\
\hline Upper tract & 1 \\
\hline Prostate & 2 \\
\hline Sarcoma & 7 \\
\hline Leiomyosarcoma & 4 \\
\hline Retroperitoneal & 3 \\
\hline Gluteal & 1 \\
\hline Rhabdomyosarcoma & 1 \\
\hline Angiosarcoma & 1 \\
\hline Unclassified & 1 \\
\hline Melanoma & 3 \\
\hline Glioblastoma multiforme & 1 \\
\hline Adrenal cortical carcinoma & 1 \\
\hline
\end{tabular}


Table 2. Detection of $\mathrm{i}(12 \mathrm{p})$ or additional copies of chromosome 12 without $\mathrm{i}(12 \mathrm{p})$ by fluorescence in situ hybridization (FISH) in primary tumors and SMNs.

\begin{tabular}{|c|c|c|c|c|c|c|c|c|c|}
\hline Case No. & Primary Testicular Tumor & $\begin{array}{l}\text { Age at Initial } \\
\text { Diagnosis }\end{array}$ & Primary Treatment & Age at SMN & $\begin{array}{c}\text { Time to SMN } \\
\text { (Yrs.) }\end{array}$ & SMN Histology & Metastatic Tumor & $\begin{array}{c}\% \text { i(12p) } \\
\text { FISH Positive }\end{array}$ & $\begin{array}{l}\# \text { i(12p) } \\
\text { Copies }\end{array}$ \\
\hline 1 & Seminoma * & 51 & BEP & 57 & 6.5 & $\begin{array}{c}\text { Unclassified } \\
\text { sarcoma }\end{array}$ & $\mathrm{RP}$ & $56 \%$ & $1-2$ \\
\hline 2 & Seminoma & 31 & XRT & 54 & 22.0 & Colorectal & Liver & $68 \%$ & 1 \\
\hline 3 & Seminoma & 28 & $\begin{array}{c}\text { XRT, BEP, HDC + } \\
\text { SCT }\end{array}$ & 34 & 5.9 & LMS & Gluteus & $64 \%$ & $1-2$ \\
\hline 4 & Seminoma & 53 & $\mathrm{BEP}$ & 56 & 3.1 & Urothelial & Bladder & $39 \%$ & 1 \\
\hline 5 & Nonseminoma & 39 & BEP & 39 & 0.4 & Pancreatic & Pancreas & $63 \%$ & $1-3$ \\
\hline Case No. & Primary Histology & $\begin{array}{l}\text { Age at Initial } \\
\text { Diagnosis }\end{array}$ & Primary Treatment & Age at SMN & $\begin{array}{l}\text { Time to SMN } \\
\text { (Yrs.) }\end{array}$ & SMN Histology & Site of SMN & $\begin{array}{c}\text { \% Extra } \\
\text { Copies } \\
\text { Chromosome } \\
12\end{array}$ & $\begin{array}{l}\# \mathrm{i}(12 \mathrm{p}) \\
\text { Copies }\end{array}$ \\
\hline 6 & Seminoma & 33 & XRT & 51 & 18.0 & LMS & $\mathrm{RP}$ & $73 \%$ & 0 \\
\hline 7 & Seminoma & 51 & XRT & 59 & 7.6 & $\begin{array}{c}\text { Rectal } \\
\text { (adenocarcinoma) }\end{array}$ & Rectum & $55 \%$ & 0 \\
\hline 8 & Seminoma & 58 & XRT & 71 & 13.3 & Colorectal & Cecum & $36 \%$ & 0 \\
\hline 9 & Seminoma & 57 & XRT & 65 & 8.5 & $\begin{array}{c}\text { Lung } \\
\text { (adenocarcinoma) }\end{array}$ & Lung & $72 \%$ & 0 \\
\hline 10 & $\begin{array}{c}\text { Seminoma } \\
\text { Nonseminoma }\end{array}$ & $\begin{array}{l}29 \\
44\end{array}$ & $\begin{array}{l}\text { XRT } \\
\text { BEP }\end{array}$ & 59 & 24.6 & Melanoma & $\begin{array}{c}\text { Axillary lymph } \\
\text { node }\end{array}$ & $83 \%$ & 0 \\
\hline 11 & Seminoma & 22 & XRT & 58 & 9.6 & LMS & $\mathrm{RP}$ & $72 \%$ & 0 \\
\hline 12 & Nonseminoma & 28 & CISCA/VB & 45 & 36.3 & LMS & $\mathrm{RP}$ & $74 \%$ & 0 \\
\hline 13 & Seminoma & 53 & XRT & 58 & 44.8 & Colorectal & Lung & $83 \%$ & 0 \\
\hline 14 & Seminoma & 62 & & 65 & 5.2 & Lung (squamous) & Lung & $61 \%$ & 0 \\
\hline 15 & Seminoma & 27 & XRT & 81 & 3.0 & Urothelial & Bladder & $66 \%$ & 0 \\
\hline 16 & NA & 20 & $\mathrm{XRT}+\mathrm{VB}$ & 57 & 53.6 & $\begin{array}{l}\text { Adrenal Cortical } \\
\text { Carcinoma }\end{array}$ & Adrenal & $89 \%$ & 0 \\
\hline 17 & Seminoma & 31 & XRT & 61 & 36.6 & Bladder & Bladder & $82 \%$ & 0 \\
\hline 18 & Seminoma & 29 & CTX/carboplatin & 49 & 29.9 & Urothelial & Renal pelvis & $51 \%$ & 0 \\
\hline 19 & Seminoma & 47 & XRT & 65 & 20.3 & $\begin{array}{l}\text { Renal cell } \\
\text { carcinoma }\end{array}$ & Kidney & $57 \%$ & 0 \\
\hline 20 & Seminoma & 29 & PVB & 54 & 19.4 & Urothelial & Bladder & $91 \%$ & 0 \\
\hline
\end{tabular}

BEP: bleomycin, etoposide, cisplatin. XRT: radiation therapy. HDC + SCT: high-dose chemotherapy + stem-cell transplantation. CEB: carboplatin, etoposide, bleomycin. PVB: cisplatin, vinblastine, bleomycin. CISCA: cyclophosphamide, doxorubicin, cisplatin. VB: vinblastine, bleomycin. CTX: cyclophosphamide. LMS: leiomyosarcoma. RP: retroperitoneum. ${ }^{*}$ Diagnosed by biopsy of retroperitoneal lymph node. Pathology of primary tumor not available. 


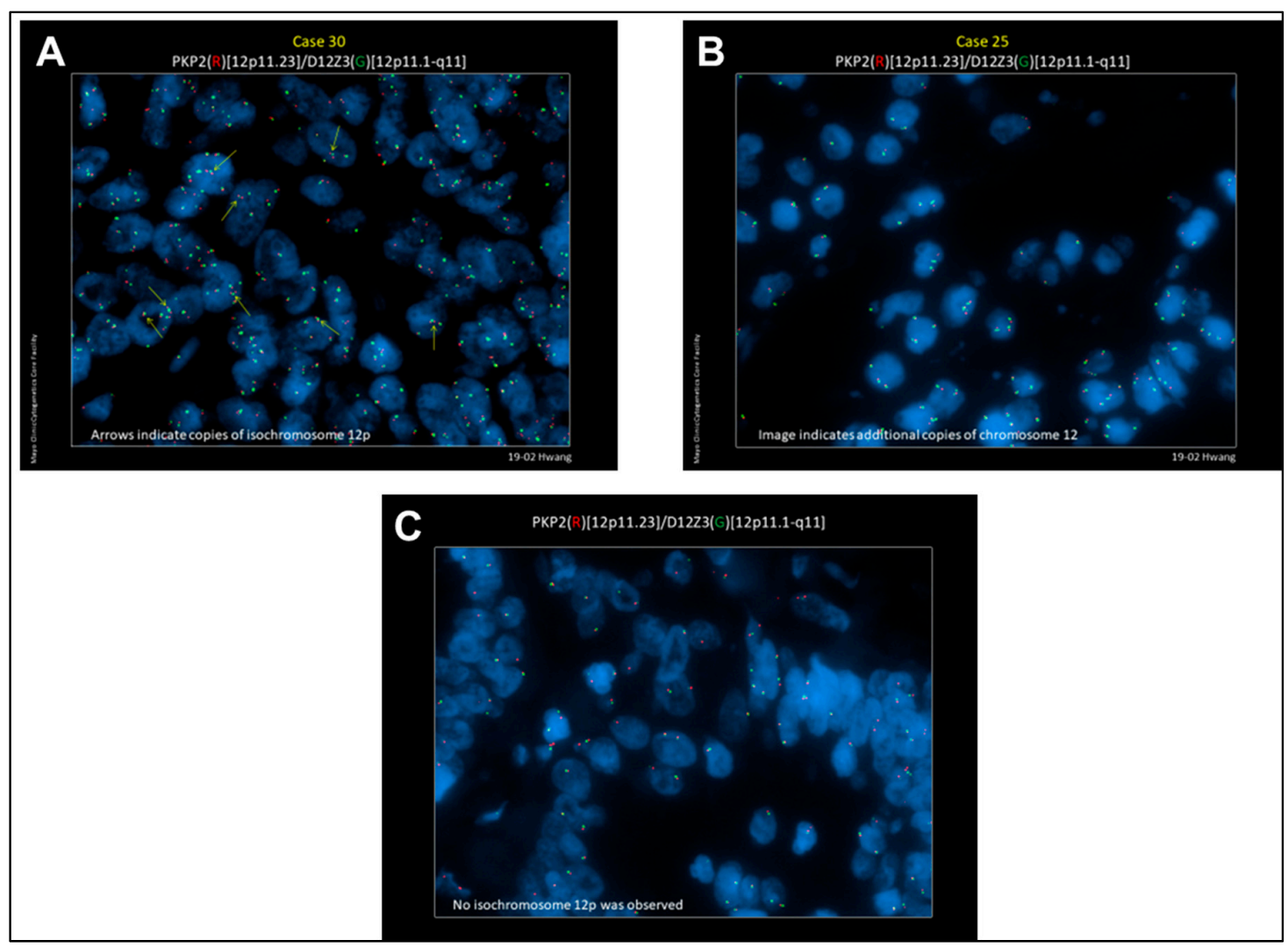

Figure 1. Representative FISH images. (A) Representative image (patient \#4) demonstrating detection of i(12p) by FISH using PKP2 DNA probe labeled with SpectrumOrange and D12Z3 probe labeled with SpectrumGreen (see text for details). (B) Representative image (patient \#13) demonstrating additional copies of chromosome 12 without detection of $\mathrm{i}(12 \mathrm{p})$. (C) Representative image demonstrating a negative control.

\subsection{Evaluation of Genetic Concordance in the Somatic Transformation of TGCTs by Targeted DNA Sequencing}

To better characterize the genetic background of somatically transformed teratoma, we identified seven patients who underwent surgical resection of a tumor with both a teratoma and somatic transformation present at a metastatic site, providing matched specimens. The clinical characteristics of these patients and the chemotherapy regimens they received are shown in Table S1. Using the T200 gene panel, we detected mutations in 58 genes across all 14 samples [19] (Figure 2). The McNemar exact test yielded no evidence of pair discordance on all genes, including 24 genes with slight discordance and others with near-perfect concordance between the teratoma and the paired somatic transformation. Among the 58 genes with mutations, the "within-patient mutation agreement" ranged from $86.2 \%$ to $94.8 \%$, indicating a high degree of concordance among the 200 genes assessed (Figure 2, Figure S1b). 
Mutations Detected on T200

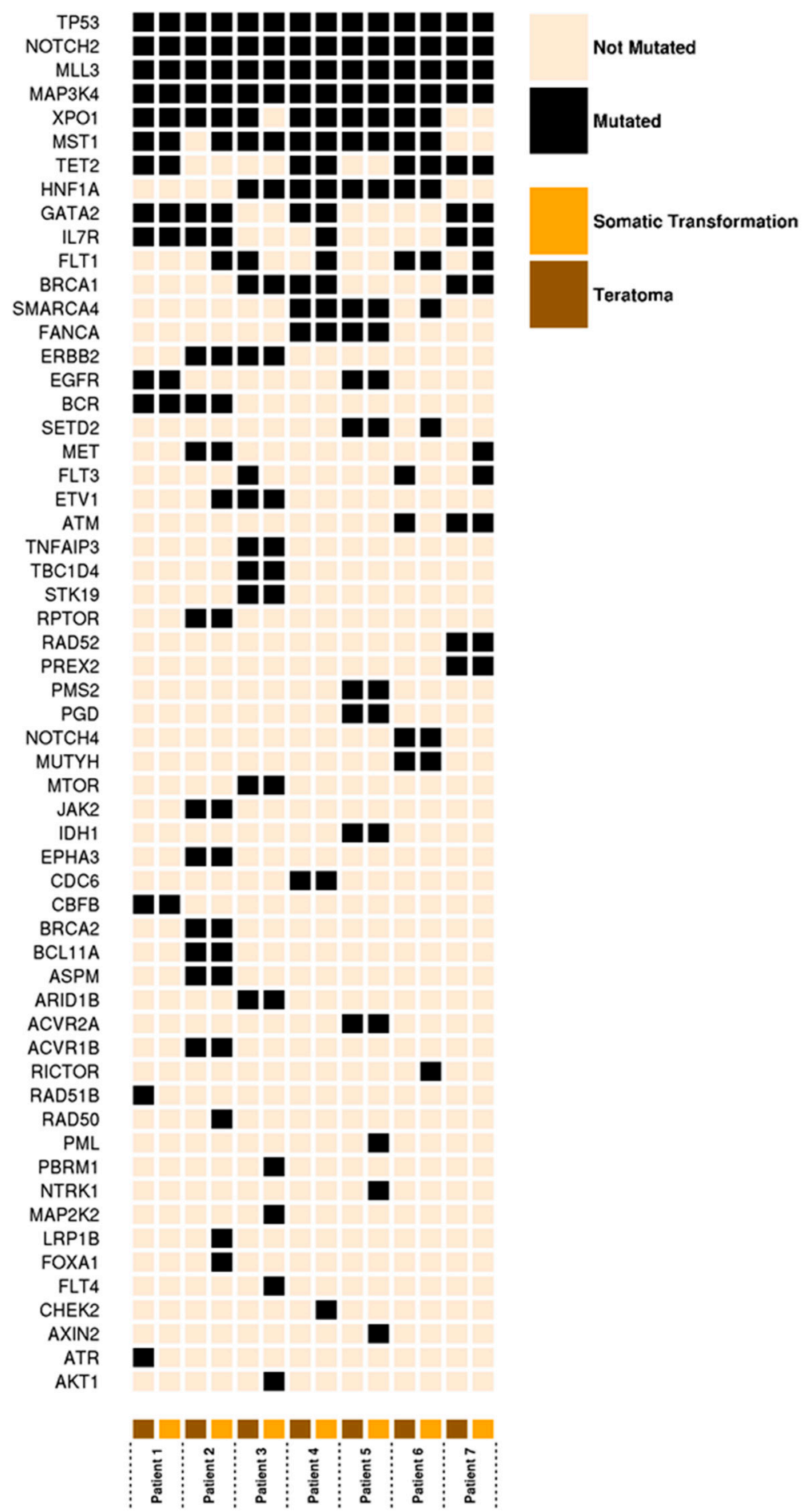

Figure 2. OncoPrint data of mutations detected in 14 samples across 7 patients.

2.3. Evaluation of Differentially Expressed Genes in Matched Teratoma and Somatically Transformed Specimens by RNAseq

We next evaluated expressed genes in our matched teratomas and somatically transformed tumors using RNAseq. We similarly observed a high degree of concordance across a majority of genes. Notably, we identified seven genes with significantly lower expression in somatically transformed 
tissue: miR-3156-1, miR-7-3HG, ARHGEF35, LZTS1-AS1, LIPN, AC243960.3, and DLX6 (Figure S1c,d). The maximum log2 fold change gene expression was moderate (2.04).

\subsection{Growth of Teratoma Cell Cultures and Xenograft}

Cell cultures were propagated from post-chemotherapy teratoma samples from two patients (Table S2), creating cell lines Tera13 and Tera22. As described in mouse teratocarcinoma cell cultures [20], classic "C" cell colonies formed in STEMium media (Figure 3A). For controls, samples of resections obtained from patients with benign post-chemotherapy masses, which contained fibrosis and necrosis, were processed identically (at the time of resection, all masses had unknown final pathology). The samples generated poorly growing colonies or no cell colonies at all. There were no "C" cell colonies identified. " $\mathrm{C}$ " and " $\mathrm{F}$ " cell colonies were able to be grown in DMEM (Figure S2a,b). Finally, the Tera13 cell line was able to successfully recapitulate teratoma formation in xenograft models (Figure 3B, Figure S3).
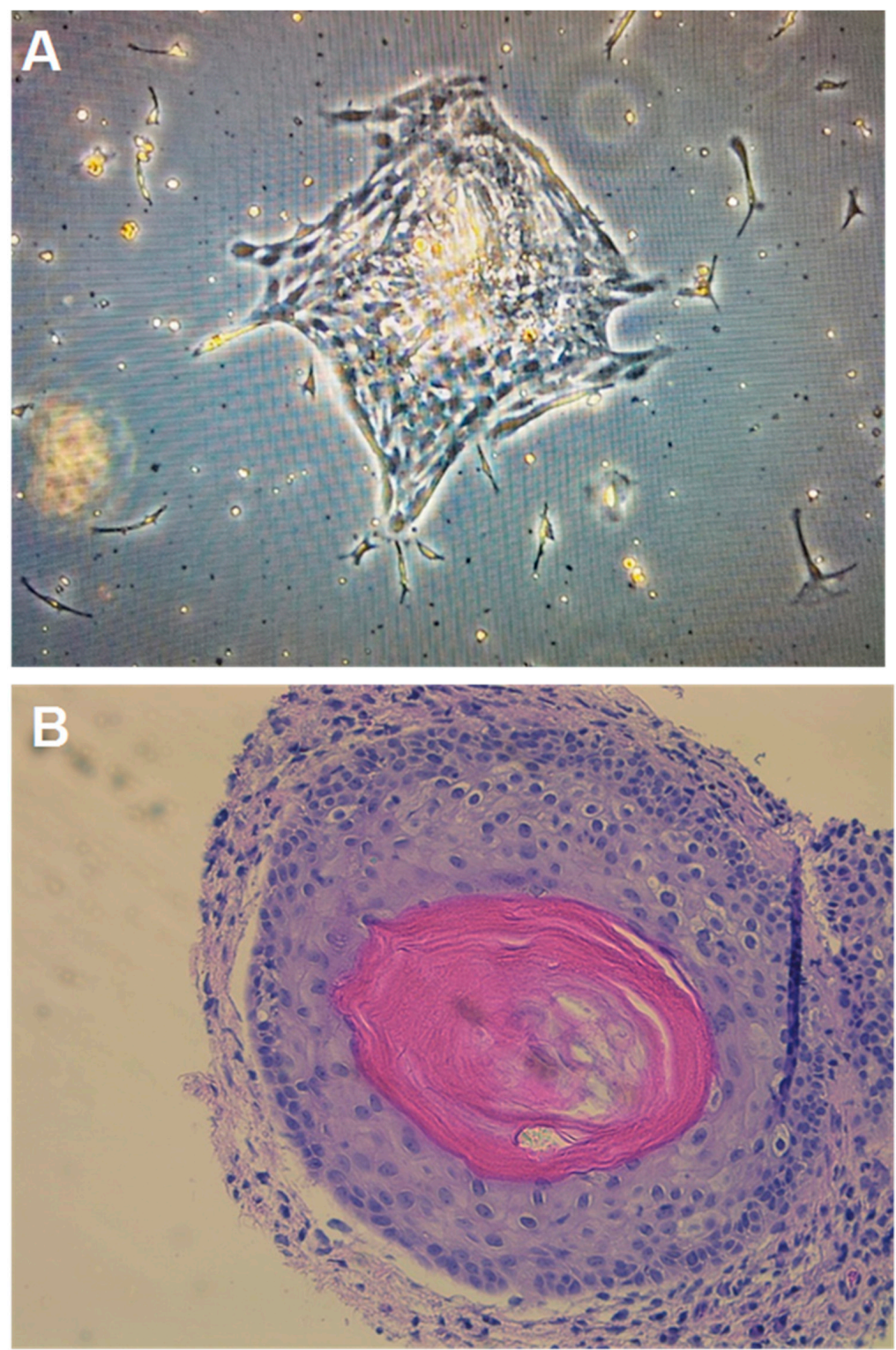

Figure 3. (A) Representative image of Tera13 growing in STEMium at passage 0, day 9. (B) Teratoma with chondrocyte and lamellar bone formation in a xenograft model. Tera13 cell line derived from primary culture of a residual mature teratoma following chemotherapy. 


\subsection{Stemness Biomarker Expression}

When tested by flow cytometry, early-passage cells expressed classic cancer-initiating cell surface markers, suggesting the stem-like and multipotent nature of these cells (Table 3) [21,22]. Approximately $50 \%$ of the cells expressed SSEA-4, a marker of normal adult spermatogonial stem cells. There was presence of CD34 (3\%) but loss of SSEA5, [23] TRA-1-60, TRA-1-81, and Cripto-1. We performed Western blots and detected NANOG but not OCT3/4 or SALL4 in Tera13, and no NANOG, OCT3/4, or SALL4 in Tera22 (Figure S4A). Uncropped Western blots are shown in Figure S4B-E.

Table 3. Tera13 and Tera22 expressed cell surface markers by flow cytometry, suggesting their stem-like and multipotent nature.

\begin{tabular}{|c|c|c|c|c|c|c|}
\hline $\begin{array}{l}\text { CSC Surface } \\
\text { Marker }\end{array}$ & Function & $\begin{array}{l}\text { Adult Stem Cell } \\
\text { Expression }\end{array}$ & $\begin{array}{l}\text { Normal Tissue } \\
\text { Expression }\end{array}$ & $\begin{array}{c}\text { CSC } \\
\text { Expression }\end{array}$ & $\begin{array}{c}\text { \% Cells Positive } \\
\text { in Cell Line } \\
\text { tera13 }\end{array}$ & $\begin{array}{c}\text { \% Cells Positive } \\
\text { in Cell Line } \\
\text { tera22 }\end{array}$ \\
\hline SSEA3 & $\begin{array}{l}\text { hESC } \\
\text { marker }\end{array}$ & Mesenchymal & Rare & $\begin{array}{c}\text { Embryonal, } \\
\text { Breast }\end{array}$ & $<1 \%$ & $<1 \%$ \\
\hline SSEA4 & $\begin{array}{l}\text { hESC } \\
\text { marker }\end{array}$ & $\begin{array}{l}\text { Mesenchymal, } \\
\text { Cardiac, Gonad }\end{array}$ & Rare & $\begin{array}{c}\text { Embryonal, } \\
\text { Breast }\end{array}$ & $55 \%$ & $55 \%$ \\
\hline SSEA5 & $\begin{array}{l}\text { hESC } \\
\text { marker }\end{array}$ & NA & Unknown & $\begin{array}{l}\text { Embryonal, } \\
\text { Pancreatic, } \\
\text { Colorectal, } \\
\text { Urothelial }\end{array}$ & $<1 \%$ & $<1 \%$ \\
\hline TRA-1-60 & $\begin{array}{l}\text { hESC } \\
\text { marker }\end{array}$ & NA & Rare & $\begin{array}{c}\text { Embryonal, } \\
\text { Breast, } \\
\text { Prostate }\end{array}$ & - & - \\
\hline TRA-1-81 & $\begin{array}{l}\text { hESC } \\
\text { marker }\end{array}$ & NA & Rare & $\begin{array}{c}\text { Embryonal, } \\
\text { Breast }\end{array}$ & - & - \\
\hline CD133 & $\begin{array}{l}\text { Marker of } \\
\text { hematopoietic } \\
\text { stem cell }\end{array}$ & $\begin{array}{l}\text { Hematopoietic, } \\
\text { Prostate, Neural }\end{array}$ & Rare & Many * & $5 \%$ & $<1 \%$ \\
\hline CD90 & $\begin{array}{c}\text { Cell } \\
\text { adhesion }\end{array}$ & $\begin{array}{l}\text { Mesenchymal, } \\
\text { Cardiac }\end{array}$ & Rare & Brain, Liver & $>99 \%$ & $>99 \%$ \\
\hline CD326 & $\begin{array}{c}\text { Cell } \\
\text { adhesion }\end{array}$ & No & Rare & $\begin{array}{l}\text { Colon, } \\
\text { Pancreas, } \\
\text { Liver }\end{array}$ & - & - \\
\hline Cripto-1 (TDGF1) & Self-renewal & NA & Rare & $\begin{array}{c}\text { Breast, } \\
\text { Colon, Lung }\end{array}$ & $4 \%$ & $5 \%$ \\
\hline CD24 & $\begin{array}{c}\text { B cell } \\
\text { proliferation }\end{array}$ & Intestinal & Rare & $\begin{array}{l}\text { Breast, } \\
\text { Gastric, } \\
\text { Pancreas }\end{array}$ & $25 \%$ & $2 \%$ \\
\hline CD117 (c-kit) & $\begin{array}{l}\text { Receptor for } \\
\text { stem cell } \\
\text { factor }\end{array}$ & $\begin{array}{l}\text { Mesenchymal, } \\
\text { Cardiac }\end{array}$ & Rare & Ovary & $2 \%$ & - \\
\hline CD26 & $\begin{array}{c}\text { Dipeptidyl } \\
\text { peptidase iv }\end{array}$ & Hematopoietic & Rare & $\begin{array}{l}\text { Colorectal, } \\
\text { Leukemia }\end{array}$ & $80 \%$ & $>99 \%$ \\
\hline CD34 & $\begin{array}{l}\text { Cell } \\
\text { adhesion }\end{array}$ & Hematopoietic & Rare & $\begin{array}{l}\text { Leukemia, } \\
\text { SCC }\end{array}$ & $3 \%$ & $2 \%$ \\
\hline CD44 & $\begin{array}{l}\text { Hyaluronic } \\
\text { acid receptor }\end{array}$ & $\begin{array}{l}\text { Hematopoietic, } \\
\text { Adipose }\end{array}$ & Rare & Many ** & $>99 \%$ & $>99 \%$ \\
\hline
\end{tabular}

CSC: cancer stem cell. hESC: human embryonic stem cell. NA: not applicable. SCC: squamous cell carcinoma. * Breast, prostate, colorectal, glioma, liver, lung, ovary; ** Squamous cell carcinoma, breast, colon, liver, ovary, pancreas, gastric.

\section{Discussion}

In this study, we detected the presence of $i(12 p)$ or gain of $12 p$ in half of the patients with SMN and a previous diagnosis of TGCT. By targeted DNA sequencing and RNAseq, we identified high genetic concordance (86-95\%) in patient-matched teratomas and somatically transformed tumors, suggesting a common clonal origin of these two clinically and pathologically distinct tumor types. We successfully established post-chemotherapy teratoma cell cultures and demonstrated the existence of progenitor cells by their expression of stemness surface markers in vitro and their exhibition of multipotency in vivo. Our findings suggest that progenitor stem-like cells of origin may account for SMN and somatic transformation, which ultimately determine the lethality of TGCT.

In our FISH studies, we did not detect $\mathrm{i}(12 \mathrm{p})$ or $12 \mathrm{p}$ gain in normal control tissues, confirming that this was a somatic rather than germline genetic aberration. According to Groot et al., the cumulative 
incidence of SMN after treatment of TGCT was similar for patients with a history of seminoma or nonseminoma (about $12.5 \%$ and $9.5 \%$ over a 25 -year period, respectively). Radiation therapy and platinum-containing chemotherapy were associated with an increased risk of solid SMN, particularly with GI SMNs in a dose-dependent manner [4]. Similar to previous studies [4,24,25], we found that SMN with positive $\mathrm{i}(12 \mathrm{p})$ or $12 \mathrm{p}$ gain could occur in a variety of organ sites. We also found that a preponderance of SMNs had occurred in patients with a history of seminoma and radiation therapy [26], and that a majority of those SMNs had actually occurred outside the irradiated field. Interestingly, while almost all patients had prior radiation therapy or chemotherapy for their TGCT treatment, one patient (\#14, Table 1), who developed an SMN in the lung, had neither.

Therefore, the development of SMN in patients with a history of TGCT is not entirely explained by DNA damage and genomic aberrations from toxic curative therapy. Interestingly, progenitor stem-like cells in the phenomenon of microchimerism can migrate to distant sites, differentiate into various cellular lineages, and remain dormant for a prolonged period. Hence, progenitor stem-like cells in fetal-to-maternal microchimerism migrate from the fetus to the mother across the placenta and form hybrid tissues within the mother. Microchimerism has been detected as early as seven weeks into pregnancy and as late as 27 years postpartum [27-30]. Similarly, progenitor stem-like cells in donor microchimerism migrate between individuals after solid organ transplantation. In cases of malignancy following solid organ transplantation, about $12 \%$ originate from the donor organ, while $8 \%$ of the malignancies in the donated organ have a recipient origin [31]. Because progenitor stem-like cells migrate and may transform in different individuals, it is conceivable that they may also do so within the same individual.

Intriguingly, the incidence of solid SMNs has remained more or less unchanged from 1980 to 2008 , despite overall deintensification of therapy [31-36], which suggests that DNA-damaging chemotherapy and radiotherapy may not fully explain SMNs and raises the hypothesis that a common cell of origin may be responsible for subsequent lethal phenotypes. A mature teratoma provides an ideal opportunity for testing this hypothesis, because (1) it is a fully differentiated tumor linked to late relapses (as in $\mathrm{SMN}$ ) and to somatic transformation, if not removed in a timely manner; and (2) it often coexists with somatically transformed malignancies, allowing investigation of their shared genetic signature and common clonal origin.

Currently, the prevailing hypothesis suggests that indigenous differentiated cells dedifferentiate and acquire stemness properties, that is, undergo transformation or reprogramming by way of genetic aberrations or mutations $[37,38]$. We sought to test this hypothesis in mature teratomas-a fully differentiated tumor that often coexists with somatically transformed malignancies within the same tumor in the same patient. We found that metastatic teratomas and their corresponding somatic transformations displayed highly concordant genetic profiles based on genome sequencing, which points to a common clonal origin and suggests that specific genetic aberrations are not responsible for dedifferentiation or somatic transformation.

Our results support a stem-cell origin of cancer and validate the importance of cellular context in TGCT patients who develop SMN [6,7]. Late TGCT recurrences and SMNs developing many years - even decades - later do not appear to be due to the acquisition and accumulation of new genetic mutations, but rather to the expression or revelation of aberrant stem-like or embryonic epigenetic phenotypes. We postulate that even minimal or minor damage to a pertinent malignant cell of origin (i.e., progenitor stem-like cells rather than progeny differentiated cells) triggers an SMN at a distant site in a distant time.

Finally, accounting for cellular context has key therapeutic implications. After all, a progenitor chemo-sensitive TGCT (e.g., an embryonal carcinoma) and a progeny chemo-resistant TGCT (e.g., a teratoma) harbor the same genetic defects due to their common clonal origins but have different epigenetic phenotypes (e.g., migratory prowess, tumor heterogeneity, and cancer dormancy) [39,40]. Furthermore, the presence of a teratoma [41] in the primary tumor suggests a potential lethal tumor phenotype, intrinsically refractory to chemotherapy and prone to somatic transformation, that may 
require an alternative therapeutic regime or strategy and can only be cured by surgical resection in a timely manner [3,42].

A limitation of this study relates to rarity of disease and paucity of clinical samples. We need to perform targeted DNA sequencing and RNASeq on matched patient specimens to compare primary tumors with SMNs as well as among SMNs in patients with more than one SMN. We also need to demonstrate that the presence and type of progenitor cells within teratomas may vary depending on the type of primary TGCT from which they arise [3,42]. However, we hope that the raised awareness from this study will spur expanded profiling on greater numbers of pertinent tumors.

\section{Materials and Methods}

\subsection{Patient Identification}

We retrospectively analyzed the tumor registry at the MD Anderson Cancer Center (MDACC) and identified 655 TGCT patients who developed a subsequent SMN between January 1990 and September 2018. We focused on 113 recent cases (since 2011) of solid tumor SMNs, of which 42 had sufficient tissue to perform fluorescence in situ hybridization (FISH) of i(12p). We also identified 7 cases between 2001 and 2008 in which the teratoma and the somatic transformation were adjacent within the same residual tumor after chemotherapy with sufficient tissue for targeted DNA and RNA sequencing.

\subsection{Fluorescent in Situ Hybridization (FISH)}

FISH was performed on unstained slides prepared from archival tissue at the Mayo Clinic Cytogenetics Core to detect the presence of $\mathrm{i}(12 \mathrm{p})$. FISH was also performed on 1 test case at the MDACC Cytogenetics Laboratory for confirmation of the results and with matched normal tissue for a negative control and the detection of germline $i(12 p)$. In brief, the working solution contained $3 \mu \mathrm{L}$ concentrated PKP2 DNA probe labeled with SpectrumOrange and $1 \mu \mathrm{L}$ of concentrated D12Z3 probe labeled with SpectrumGreen (Abbott Molecular/Vysis Products, Abbott Park, IL, USA) in $16 \mu \mathrm{L}$ of LSI/WCP hybridization buffer (Abbott Laboratories). Two technologists independently scored 50 qualifying tumor nuclei for each sample. In the event of a discrepancy, a third technologist would also score the sample and report the original score closest to its value. The normal cutoff value for enumeration of the $\mathrm{i}(12 \mathrm{p})$ probe set with $95 \%(p<0.05)$ confidence level was $30 \%$ [43].

\subsection{DNA and RNA Sequencing}

Details of RNA and cDNA library preparation and capture are provided in Supplementary Methods. The captured libraries were sequenced on a HiSeq 2500 (Illumina Inc., San Diego, CA, USA) on a version 3 TruSeq paired-end flow cell according to the manufacturer's instructions at a cluster density between 700 and $1000 \mathrm{~K}$ clusters $/ \mathrm{mm}^{2}$. Density is measured as $1000(\mathrm{~K})$ clusters per square millimeter $\left(\mathrm{mm}^{2}\right)$. Sequencing was performed for $2 \times 100$ paired-end reads with a $7 \mathrm{nt}$ read for indexes using cycle sequencing v3 reagents (Illumina). The resulting BCL files containing the sequence data were converted into FASTQ files, and individual libraries within the samples were de-multiplexed using CASAVA 1.8.2 with no mismatches. All regions were covered by $>20$ reads.

\subsection{Primary Culture, Flow Cytometry, and Xenograft}

We procured and propagated post-chemotherapy teratoma cells, as described in the Supplementary Methods. In short, tumor cells were incubated at $37^{\circ} \mathrm{C}$ in $10 \% \mathrm{CO}_{2}$ and $5 \% \mathrm{O}_{2}$ in STEMium-a human pluripotent stem cell growth medium (ScienCell, Carlsbad, CA, USA). The culture medium was changed every 2 days and the cells passed as necessary with $80 \%$ to $90 \%$ confluence. The final pathology of teratoma in the patient was confirmed within 7 days. Cell line samples were stained live for cell-surface stemness markers expressed on hESCs and cancer stem cells. Details of flow cytometry analysis are provided in the Supplementary Methods [20]. Early passages were injected in SCID mice and are further described in the Supplementary Methods. 


\subsection{DNA Sequencing Analysis}

The FASTQ data from Illumina HiSeq were processed at the Institute for Personalized Cancer Therapy (IPCT) at MD Anderson through standard pipelines outlined at https://www.ncbi.nlm.nih. gov/pmc/articles/PMC4511273/. In essence, the target-capture deep-sequencing data were aligned to human reference assembly hg19 using BWA, and duplicated reads were removed using Picard. The single nucleotide variants (SNVs) and small indels were called by an in-house analysis pipeline, which classified variants into 3 categories, somatic, germline, and loss of heterozygosity, based on variant allele frequencies in the tumor and the matched normal tissues.

\subsection{RNA Sequencing Analysis}

The FASTQ data were processed by an in-house RNAseq data analysis pipeline, which used the STAR aligner [44] to align raw reads to the hg19 human reference genome, followed by Oncofuse [45] to filter and prioritize fusion candidates, then the use of featureCounts [46] to quantify aligned reads to produce raw counts, and FastQC and Qualimap [47] to evaluate the quality of raw reads and feature counts. Hierarchical clustering and k-means unsupervised clustering algorithms were used to cluster samples according to their RNAseq expression profiles. The details of the sequencing analysis and interpretation are provided in the Supplementary Methods.

\subsection{Concordance of Mutations}

To assess the within-subject mutation concordance/discordance between teratoma and somatic transformation samples, we conducted the McNemar exact test against the null hypothesis of concordance (i.e., the equal proportion of discordant pairs) on each of 58 genes on the T200 panel with detected mutation.

\section{Conclusions}

In summary, we detected $\mathrm{i}(12 \mathrm{p})$ or gain of $12 \mathrm{p}$ in a substantial number of SMNs among patients with a history of TGCT and demonstrated high genetic concordance between their teratoma and adjacent somatically transformed tumor, with few differentially expressed genes, suggesting that specific genetic aberrations are not major drivers of somatic transformation. We discovered putative progenitor cells embedded within mature teratomas and were able to recapitulate teratoma formation in one case of a xenograft cell line, suggesting that progenitor cells differentiate into diverse cellular lineages $[48,49]$ rather than progeny cells dedifferentiating into stem-like cells through genetic mutations. Further studies in additional patients are warranted to confirm whether a progenitor stem-like cell of origin could account for both SMN development and somatic transformation in patients with a history of TGCT.

Supplementary Materials: The following are available online at http://www.mdpi.com/2072-6694/12/12/3755/s1: Figure S1a: Violin plot of FISH data plotted by tumor site, Figure S1b: Genetic concordance between matched teratoma and somatic transformation specimens, Figure S1c: Differentially expressed genes identified from RNA-Seq, Figure S1d: Volcano Plot: Differential expression of all RNA-Seq genes, Figure S2: " $\mathrm{C}$ " and " $\mathrm{F}$ " cell colonies forming in DMEM base media, Figure S3: Resection of tumor from SCID mouse and representative H\&E slides of the tumor after xenograft injection with tera13, Figure S4: Western blots, Table S1: Clinical characteristics and chemotherapy regimens of matched teratoma and somatic transformation specimens., Table S2: Clinical characteristics of patients from whom cell lines tera13 and tera21 derived.

Author Contributions: Conception and design, E.C.U., B.A.S., M.J.H. and S.-M.T.; acquisition of data, E.C.U., B.A.S., M.J.H., A.Y.J., M.E.W., K.W.M., H.A., J.U., T.G., J.A.M., J.F.W., J.A.K., C.G.W., L.L.P., M.Z. and S.-M.T.; analysis and interpretation of data, E.C.U., B.A.S., M.J.H., A.Y.J., M.Z., T.G. and S.-M.T.; drafting of manuscript, E.C.U., B.A.S., M.J.H. and S.-M.T.; project administration and resources: T.M.; critical revision of manuscript, all authors. All authors have read and agreed to the published version of the manuscript.

Funding: This study was supported in part by donations from the Realan Foundation and Harendra Mankodi (SMT). The sequencing and data generation was supported by grant CA016672 (ATGC) from the University of Texas MD Anderson Cancer Center, Advanced Technology Genomics Core. 
Acknowledgments: We thank Sarah Townsend for editorial assistance. We are also grateful to Patricia T. Greipp, D.O. (Director), Darlene Knutson, Sara Kloft-Nelson, and Ryan Knudson from the Mayo Clinic Cytogenetics Core services for performing the FISH analysis. Pre-sequencing processing work was carried out in the Cancer Genomics Laboratory at the University of Texas MD Anderson Cancer Center Sheikh Khalifa Bin Zayed Al Nahyan Institute for Personalized Cancer Therapy.

Conflicts of Interest: The authors declare no conflict of interest.

\section{References}

1. Siegel, R.L.; Miller, K.D.; Jemal, A. Cancer statistics. CA Cancer J. Clin. 2020, 70, 7-30. [CrossRef] [PubMed]

2. Van Dijk, M.R.; Steyerberg, E.W.; Habbema, J.D.F. Survival of non-seminomatous germ cell cancer patients according to the IGCC classification: An update based on meta-analysis. Eur. J. Cancer 2006, 42, 820-826. [CrossRef] [PubMed]

3. Tu, S.; Bilen, M.A.; Hess, K.R.; Broaddus, R.R.; Kopetz, S.; Wei, C.; Pagliaro, L.C.; Karam, J.A.; Ward, J.F.; Wood, C.G.; et al. Intratumoral heterogeneity: Role of differentiation in a potentially lethal phenotype of testicular cancer. Cancer 2016, 122, 1836-1843. [CrossRef] [PubMed]

4. Groot, H.J.; Lubberts, S.; de Wit, R.; Witjes, J.A.; Kerst, J.M.; de Jong, I.J.; Groenewegen, G.; van den Eertwegh, A.J.M.; Poortmans, P.M.; Klümpen, H.-J.; et al. Risk of solid cancer after treatment of testicular germ cell cancer in the platinum era. J. Clin. Oncol. 2018, 36, 2504-2513. [CrossRef]

5. Kum, J.B.; Ulbright, T.M.; Williamson, S.R.; Wang, M.; Zhang, S.; Foster, R.S.; Grignon, D.J.; Eble, J.N.; Beck, S.D.; Cheng, L. Molecular genetic evidence supporting the origin of somatic-type malignancy and teratoma from the same progenitor cell. Am. J. Surg. Pathol. 2012, 36, 1849-1856. [CrossRef]

6. Tu, S.M. Origin of Cancers: Clinical Perspectives and Implications of a Stem-Cell Theory of Cancer; Springer: New York, NY, USA, 2010.

7. Tu, S.M. Story of Hydra: Portrait of Cancer as a Stem-Cell Disease; Nova: New York, NY, USA, 2019.

8. Nettersheim, D.; Gillis, A.J.M.; Looijenga, L.H.; Schorle, H. TGF- $\beta 1$, EGF and FGF4 synergistically induce differentiation of the seminoma cell line T Cam-2 into a cell type resembling mixed non-seminoma. Int. J. Androl. 2011, 34, e189-e203. [CrossRef]

9. Bouskine, A.; Vega, A.; Nebout, M.; Benahmed, M.; Fenichel, P. Expression of embryonic stem cell markers in cultured JKT?1, a cell line derived from a human seminoma. Int. J. Androl. 2010, 33, 54-63. [CrossRef]

10. Som, A.; Xiao, L.; Zhu, R.; Guo, C.C.; Xiao, L.; Rao, P.; Efstathiou, E.; Matin, A.; Tu, S. Clinically atypical seminomas with yolk sac tumor features. Can. J. Urol. 2013, 20, 6860-6867.

11. Looijenga, L.H.J.; Oosterhuis, J.W. Pathogenesis of testicular germ cell tumors. Rev. Reprod. 1999, 4, 90-100. [CrossRef]

12. Van Echten, J.; Oosterhuis, J.W.; Looijenga, L.H.J.; Van De Pol, M.; Wiersema, J.; Meerman, G.J.T.; Koops, H.S.; Sleijfer, D.T.; De Jong, B. No recurrent structural abnormalities apart from i(12p) in primary germ cell tumors of the adult testis. Genes Chromosom. Cancer 1995, 14, 133-144. [CrossRef]

13. Suijkerbuijk, R.F.; Sinke, R.J.; Meloni, A.M.; Parrington, J.M.; van Echten, J.; de Jong, B.; Oosterhuis, J.W.; Sandberg, A.A.; Geurts van Kessel, A. Overepresentation of chromosome 12p sequences and karyotypic evolution in $\mathrm{i}(12 \mathrm{p})$-negative testicular germ cell tumors revealed by fluorescence in situ hybridization. Cancer Genet. Cytogenet. 1993, 70, 85-93. [CrossRef]

14. Reuter, V.E. Origins and molecular biology of testicular germ cell tumors. Mod. Pathol. 2005, 18, S51-S60. [CrossRef] [PubMed]

15. Bahrami, A.; Ro, J.Y.; Ayala, A.G. An overview of testicular germ cell tumors. Arch. Pathol. Lab. Med. 2007, 131, 1267-1280. [PubMed]

16. Ottesen, A.M.; Skakkebaek, N.E.; Lundsteen, C.; Leffers, H.; Larsen, J.; Meyts, E.R.-D. High-resolution comparative genomic hybridization detects extra chromosome arm 12p material in most cases of carcinoma in situ adjacent to overt germ cell tumors, but not before the invasive tumor development. Genes Chromosom. Cancer 2003, 38, 117-125. [CrossRef]

17. Heinonen, K.; Rao, P.N.; Slack, J.L.; Cruz, J.; Bloomfield, C.D.; Mrózek, K. Isochromosome 12p in two cases of acute myeloid leukemia without evidence of germ cell tumor. Br. J. Haematol. 1996, 93, 677-680. [CrossRef]

18. Cormier-Daire, V.; Le Merrer, M.; Gigarel, N.; Morichon, N.; Prieur, M.; Lyonnet, S.; Vekemans, M.; Munnich, A. Prezygotic origin of the isochromosome 12p in Pallister-Killian syndrome. Am. J. Med. Genet. 1997, 69, 166-168. [CrossRef] 
19. Chen, K.; Meric-Bernstam, F.; Zhao, H.; Zhang, Q.; Ezzeddine, N.; Tang, L.Y.; Qi, Y.; Mao, Y.; Chen, T.; Chong, Z.; et al. Clinical actionability enhanced through deep targeted sequencing of solid tumors. Clin. Chem. 2015, 61, 544-553. [CrossRef]

20. Martin, G.R.; Evans, M.J. The morphology and growth of a pluripotent teratocarcinoma cell line and its derivatives in tissue culture. Cell 1974, 2, 163-172. [CrossRef]

21. Kim, W.T.; Ryu, A.C.J. Cancer stem cell surface markers on normal stem cells. BMB Rep. 2017, 50, $285-298$. [CrossRef]

22. Finõnes, R.R.; Yeargin, J.; Lee, M.; Kaur, A.P.; Cheng, C.; Sun, P.; Wu, C.; Nguyen, C.; Wang-Rodriguez, J.; Meyer, A.N.; et al. Early human prostate adenocarcinomas harbor androgen-independent cancer cells. PLOS ONE 2013, 8, e74438. [CrossRef]

23. Tang, C.; Lee, A.S.; Volkmer, J.P.; Sahoo, D.; Nag, D.; Mosley, A.R.; Inlay, M.A.; Ardehali, R.; Chavez, S.L.; Pera, R.R.; et al. An antibody against SSEA-5 glycan on human pluripotent stem cells enables removal of teratoma-forming cells. Nat. Biotechnol. 2011, 29, 829-834. [CrossRef] [PubMed]

24. Travis, L.B.; Fosså, S.D.; Schonfeld, S.J.; McMaster, M.L.; Lynch, C.F.; Storm, H.H.; Hall, P.; Holowaty, E.J.; Andersen, A.; Pukkala, E.; et al. Second cancers among 40576 testicular cancer patients: Focus on long-term survivors. J. Natl. Cancer Inst. 2005, 97, 1354-1365. [CrossRef] [PubMed]

25. Robinson, D.; Moller, H.; Horwich, A. Mortality and incidence of second cancers following treatment for testicular cancer. Br. J. Cancer 2007, 96, 529-533. [CrossRef] [PubMed]

26. Kvammen, Ø.; Myklebust, T.A.; Solberg, A.; Møller, B.; Klepp, O.H.; Fosså, S.D.; Tandstad, T. Causes of inferior relative survival after testicular germ cell tumor diagnosed 1953-2015: A population-based prospective cohort study. PLoS ONE 2019, 14, e0225942. [CrossRef] [PubMed]

27. Bianchi, D.W.; Zickwolf, G.K.; Weil, G.J.; Sylvester, S.; DeMaria, M.A. Male fetal progenitor cells persist in maternal blood for as long as 27 years postpartum. Proc. Natl. Acad. Sci. USA 1996, 93, 705-708. [CrossRef] [PubMed]

28. Evans, P.C.; Lambert, N.; Maloney, S.; Furst, D.E.; Moore, J.M.; Nelson, J.L. Long-term fetal microchimerism in peripheral blood mononuclear cell subsets in healthy women and women with scleroderma. Blood 1999, 93, 2033-2037. [CrossRef] [PubMed]

29. Pritchard, S.; Wick, H.C.; Slonim, D.K.; Johnson, K.L.; Bianchi, D.W. Comprehensive analysis of genes expressed by rare microchimeric fetal cells in the maternal mouse lung. Biol. Reprod. 2012, 87, 1-6. [CrossRef]

30. Chan, W.F.N.; Gurnot, C.; Montine, T.J.; Sonnen, J.A.; Guthrie, K.A.; Nelson, J.L. Male Microchimerism in the human female brain. PLoS ONE 2012, 7, e45592. [CrossRef]

31. Barsky, S.H.; Ye, Y.; Xiao, Y.; Yearsley, K. Insights into the stem cell origin of human cancers by studying a registry of bone marrow and other organ transplant recipients who later developed solid cancers. J. Clin. Oncol. 2008, 26, 11010. [CrossRef]

32. Fung, C.; Fossa, S.D.; Milano, M.T.; Oldenburg, J.; Travis, L.B. Solid tumors after chemotherapy or surgery for testicular nonseminoma: A population-based study. J. Clin. Oncol. 2013, 31, 3807-3814. [CrossRef]

33. Jones, W.G.; Fossa, S.D.; Mead, G.M.; Roberts, J.T.; Sokal, M.; Horwich, A.; Stenning, S.P. Randomized trial of 30 versus $20 \mathrm{~Gy}$ in the adjuvant treatment of stage I testicular seminoma: A report on Medical Research Council Trial TE18, European Organization for the Research and Treatment of cancer trial 30942. J. Clin. Oncol. 2005, 23, 1200-1208. [CrossRef] [PubMed]

34. Feldman, D.R.; Bosl, G.J.; Sheinfeld, J.; Motzer, R.J. Medical treatment of advanced testicular cancer. JAMA 2008, 299, 672-684. [CrossRef] [PubMed]

35. Kollmannsberger, C.; Tyldesley, S.; Moore, C.; Chi, K.N.; Murray, N.; Daneshmand, S.; Black, P.; Duncan, G.; Hayes-Lattin, B.; Nichols, C. Evolution in management of testicular seminoma: Population-based outcomes with selective utilization of active therapies. Ann. Oncol. 2011, 22, 808-814. [CrossRef] [PubMed]

36. Hanna, N.H.; Einhorn, L.H. Testicular cancer: A reflection on 50 years of discovery. J. Clin. Oncol. 2014, 32, 3085-3092. [CrossRef]

37. Takahashi, K.; Tanabe, K.; Ohnuki, M.; Narita, M.; Ichisaka, T.; Tomoda, K.; Yamanaka, S. Induction of pluripotent stem cells from adult human fibroblasts by defined factors. Cell 2007, 131, 861-872. [CrossRef]

38. Yu, J.; Vodyanik, M.A.; Smuga-Otto, K.; Antosiewicz-Bourget, J.; Frane, J.L.; Tian, S.; Nie, J.; Jonsdottir, G.A.; Ruotti, V.; Stewart, R.; et al. Induced pluripotent stem cell lines derived from human somatic cells. Science 2007, 318, 1917-1920. [CrossRef] 
39. Jones, T.D.; Wang, M.; Sung, M.-T.; Zhang, S.; Ulbright, T.M.; Eble, J.N.; Beck, S.D.; Foster, R.S.; Anagnostou, J.J.; Conner, C.; et al. Clonal origin of metastatic testicular teratomas. Clin. Cancer Res. 2006, 12, 5377-5383. [CrossRef]

40. Kernek, K.M.; Ulbright, T.M.; Zhang, S.; Billings, S.D.; Cummings, O.W.; Henley, J.D.; Michael, H.; Brunelli, M.; Martignoni, G.; Foster, R.S.; et al. Identical allelic losses in mature teratoma and other histologic components of malignant mixed germ cell tumors of the testis. Am. J. Pathol. 2003, 163, 2477-2484. [CrossRef]

41. Funt, S.A.; Patil, S.; Feldman, D.R.; Motzer, R.J.; Bajorin, D.F.; Sheinfeld, J.; Tickoo, S.K.; Reuter, V.E.; Bosl, G.J. Impact of teratoma on the cumulative incidence of disease-related death in patients with advanced germ cell tumors. J. Clin. Oncol. 2019, 37, 2329-2337. [CrossRef]

42. Bilen, M.A.; Hess, K.R.; Campbell, M.T.; Wang, J.; Broaddus, R.R.; Karam, J.A.; Ward, J.F.; Wood, C.G.; Choi, S.L.; Rao, P.; et al. Intratumoral heterogeneity and chemoresistance in nonseminomatous germ cell tumor of the testis. Oncotarget 2016, 7, 86280-86289. [CrossRef]

43. Graham, R.P.; Jin, L.; Knutson, D.L.; Kloft-Nelson, S.M.; Greipp, P.T.; Waldburger, N.; Roessler, S.; Longerich, T.; Roberts, L.R.; Oliveira, A.M.; et al. DNAJB1-PRKACA is specific for fibrolamellar carcinoma. Mod. Pathol. 2015, 28, 822-829. [CrossRef] [PubMed]

44. Dobin, A.; Davis, C.A.; Schlesinger, F.; Drenkow, J.; Zaleski, C.; Jha, S.; Batut, P.; Chaisson, M.; Gingeras, T.R. STAR: Ultrafast universal RNA-seq aligner. Bioinformatics 2013, 29, 15-21. [CrossRef] [PubMed]

45. Shugay, M.; De Mendíbil, I.O.; Vizmanos, J.L.; Novo, F.J. Oncofuse: A computational framework for the prediction of the oncogenic potential of gene fusions. Bioinformatics 2013, 29, 2539-2546. [CrossRef] [PubMed]

46. Liao, Y.; Smyth, G.K.; Shi, W. featureCounts: An efficient general purpose program for assigning sequence reads to genomic features. Bioinformatics 2013, 30, 923-930. [CrossRef] [PubMed]

47. Okonechnikov, K.; Conesa, A.; García-Alcalde, F. Qualimap 2: Advanced multi-sample quality control for high-throughput sequencing data. Bioinformatics 2016, 32, 292-294. [CrossRef]

48. Clark, A.T.; Bodnar, M.S.; Fox, M.; Rodriquez, R.T.; Abeyta, M.J.; Firpo, M.T.; Pera, R.A.R. Spontaneous differentiation of germ cells from human embryonic stem cells in vitro. Hum. Mol. Genet. 2004, 13, 727-739. [CrossRef]

49. Gordeeva, O.F.; Zinovieva, R.; Smirnova, Y.; Payushina, O.; Nikonova, T.; Khrushchov, N. Differentiation of embryonic stem cells after transplantation into peritoneal cavity of irradiated mice and expression of specific germ cell genes in pluripotent cells. Transplant. Proc. 2005, 37, 295-298. [CrossRef]

Publisher's Note: MDPI stays neutral with regard to jurisdictional claims in published maps and institutional affiliations.

(C) 2020 by the authors. Licensee MDPI, Basel, Switzerland. This article is an open access article distributed under the terms and conditions of the Creative Commons Attribution (CC BY) license (http://creativecommons.org/licenses/by/4.0/). 